\title{
Enhancing the Satisfaction of Consumers of Tourism Services, a Core Element of the Marketing Polices
}

\author{
Cătălina Lache and Alexandru Trifu \\ Universitatea „Petre Andrei” din laşi, România
}

\begin{abstract}
Consumer's satisfaction is vital for the tourism companies. Leaving aside the fact that it is associated by the marketing specialists with the outcome of the purchasing and consumption processes, with consumers' loyalty and with company profitability, the satisfaction degree of the tourism services consumers derives from the highest wishes, of accomplishing the cultural, artistic needs of communion with the nature, of rest, relaxation, of being beside those who share the same hobbies with us. This is why, both the producers, the tourism services providers, and the suppliers are particularly interested in the way in which the clients perceive the overall tourism product, but also each of the services encompassed by the service package.
\end{abstract}

The exact evaluation of the clients' satisfaction has become a central element of the marketing policies, next to the quality policy. The enhancement of the satisfaction stands at the basis of the loyalty raising policies and aims the clients, but also the employees, the shareholders and the suppliers.

The paper presents the results of the research performed between 01.01.2010 and 01.09.2010. The matter under study consists of two distinct samples: 180 clients chosen randomly of the data bank held by 3 companies in the field of tourism (hotel, restaurant and tourism agency) and a sample of 50 employees, who are employees with the 3 analysed companies, residing in Romania, in the N-E region. The research method consists in making a poll, measuring opinions on an ordinal Likert scale, and in processing the information.

The results reflect the concern for the thorough evaluation of the consumer's satisfaction and its enhancement. Our study emphasises the importance of tourism services in Romania North-East, in order to absorb labour force and to ensure consumers' high satisfaction, for leisure time and for refill "the batteries" for working activities.

Keywords: Consumers' (degree of) satisfaction, quality, tourism products

Copyright (C) 2011 Cătălina Lache and Alexandru Trifu. This is an open access article distributed under the Creative Commons Attribution License unported 3.0, which permits unrestricted use, distribution, and reproduction in any medium, provided that original work is properly cited. Contact author: Cătălina Lache

E-maill: catalina_lache@yahoo.com 


\section{Introduction}

The aim of this paper is to highlight the way in which the efforts regarding the implementation of the quality management is reflected in the customers' perceptions.

The incursion into the theoretical level with reference to the quality and the consumers' satisfaction translates these concepts into the particular field of the tourism services. They have specific characteristics, due to the multiple heterogeneous services that make up the global service package, that are strongly affected by seasonality and by their perishable nature, which imposes the thorough sequential organization and the early distribution.

The research highlights the evaluation of the client's degree of satisfaction, ranks its causes and determines the sources of improvement of the quality of the tourism products and of enhancing the consumers' degree of satisfaction. The employees who have direct contacts with the clients are analysed, in their turn, with respect to their work satisfaction and to its impact upon the consumers' perceptions.

\section{Theoretical Framework}

The consumer's satisfaction is a consequence of the purchasing activities, of the consumption and of the use of some goods and services and defines both as an emotional answer, and a cognitive answer.

The specialty literature mentions numerous and various definitions with respect to the consumer's satisfaction. There are two points of view that have particularly imposed themselves, as follows:

- The Howard-Seth- Concept - defines the satisfaction/dissatisfaction as a psychological state that reflects the adequacy/inadequacy of the buyer's effort to purchase certain products and/or services, to his/her expectations with respect to the relation quality-price (Howard J. A., Seth J., N., 1969);

- The Hunt- Concept defines satisfaction as an evaluation based on the knowledge and the consumers' experience, which according to them, assumes a qualitative level for the respective product/service. (Hunt, S.D., Morgan, R., M., 1994)

The concepts presented highlight the psychological nature of satisfaction, as the result of the post-consumption evaluation, but also its relative character, depending on the consumer's cognitive structures. The evaluation process is related to the previous experiences, to the already shaped attitude, which under the impact of a new purchasing and consumption experience will confirm or decline the expectations, contributing to the shaping of a new attitude or it will consolidate the previous one.

Although specialty literature comprises a wide range of definitions, all of them share some essential aspects, such as:

- the consumer's satisfaction is an answer (emotional or cognitive);

- the answer has a certain target (expectations, products, consumption experience), that it has to be relative and subjective;

- the concept of satisfaction is situational, having a provisional character (it refers to a particular situation);

- The answer manifests itself at a given moment (during consumption or postconsumption, after the choice of the product and of the supplier etc.) and develops in time.

The concept of satisfaction/ dissatisfaction is tightly linked to the consumer's attitudes. The expectations which precede the purchase match the consumers' attitude before the purchase and the consumption of the product. The satisfaction matches the confirmation of the expectations, reinforcing the original attitude, while the dissatisfaction refers to the refutation of the expectations, leading to the change in the original attitude towards the product/service, the supplier or the purchase situation because of the consumption attitude they had (Oliver, 1989). 
The satisfaction is generally presented as a one-dimension concept, described by two opposing factors: satisfaction and dissatisfaction. (Maddox, 1981).

Oliver (1989) suggests a classification of the satisfaction, which is far more shaded, and which is based on a typology of the emotional reactions, as follows:

- The Content - reflects the absence of the dissatisfaction and may be highlighted, as a rule in the situations of weak involvement;

- The Pleasure - reflects the emotional reaction that might match the purchase or the consumption of a product, the habit of going to shopping centres or the experiential consumption;

- The Relief - reflects a person's emotional state who managed to avoid the occurrence of a negative experience, due to poor information, to the cognitive disparity or to other objective or subjective factors;

- The Newness - reflects the degree to which the epistemic needs are satisfied, according to which the purchase must satisfy the need of having something new, different from the previous products or experiences:

- The Surprise - differentiates from the previous states, by the fact that a consumer receives something he wouldn't have expected or looked for particularly.

All the emotional reactions towards the purchase and consumption situations may be positive or negative, the most important challenge for the specialists residing in determining the manner of shaping and measuring the satisfaction under concrete consumption circumstances, with a view to minimizing dissatisfaction and maximizing satisfaction.

Most of the marketers agree with the fact that the consumer's satisfaction matches the confirmation/refutation paradigm of the consumer's expectations. ${ }^{1}$

1 Adjusted after: Oliver, R., (1980)- A Cognitive Model The Antecedentes and Consequences of
Satisfaction is formed as a consequence of the comparative process, having four main constitutive parts:

- the appreciation of the product/service performance during consumption or postconsumption and matches the quality perceived with reference to a consumption experience;

- the consumer's expectations which are previous to the purchase or to the consumption, match the performance, hence, the expected quality, and represent a reference standard;

- the comparison between the expected and the perceived performance/ quality as a consequence of consumption will lead to the confirmation or refutation of the expectations (positive experience, negative experience, neutral);

- The confirmation will generate the consumer's satisfaction while the refutation will generate dissatisfaction.

The core elements of the model consist in the manner in which a consumer builds its reference standards, and the concept of confirmation which will generate satisfaction.

The Reference Standards or the Consumer's expectations represent the beliefs that the consumer has made of a product or service before actually consuming it. The standards are shaped by information or by means of previous concrete

Satisfaction Decision, Journal of Marketing Research, November, 17, pp 460-469; Oliver, R., L., (1993) Assessing the Dimensionality of the Consumer Ressearch, june, 20, pp 23-45; Wetsbrook, R., Reilly, M., D., (1983) -Value Percept Disparity: An Alternative to the Disconfirmation of Expectations Theory of Customer Satisfaction, Advances in Consumer Research, Associations for Consumer Research, pp 256-261; Evrard, Y., (1993)- La satisfaction des Consommateurs: Etat des Recherches, Revue Francaise du Marketing, 155/145, pp53-65; Lache, C., (2005) -Măsurarea satisfacției clienților, în volumul Economia Românească în Contextul Integrării Europene, Anuar Tomul XV, pp 349-359. 
consumption experiences and represent a result of the expressed judgements in terms of needs, wishes, costs and foreseen benefits.

The Theory of Equity is based on the feeling of being correctly treated as against the paid price, which matches the qualitative standards. In case of the products/services characterized by recurrent consumption, the quality which matches the expectations has a concrete base, those of the previous experiences, while in the case of the new products/ services, the expectations are general and abstract, in terms of values and wishes, which are shaped exclusively on the basis of some performance anticipation.

The Confirmation Concept characterizes the results of the confrontation between the original expectations and the quality perceived, and form a connection with both the cognitive aspects and the emotional ones, as follows:

- The differences between the original expectations and the quality perceived from a cognitive point of view refer to the traits that give the product its usefulness. In the case of new experiences, the convergence of the new information with the information deriving from previous experiences lead to the shaping of the expectations that will be evaluated within the consumption process.

- The emotional aspects (surprise, happiness, and ecstasy) derive from the symbolic and imaginary components of the products and services, being based on the assigning of a special meaning to the product, or to some of its traits. The difference between the expectations and their confirmation/refutation will generate positive or negative emotional states, pleasure or displeasure.

There are opinions in the specialty literature according to which the concepts of quality and consumer's satisfaction interpenetrate. Still there are clear-cut differentiations between the quality of the products/services and the satisfaction, in the following respects (Llosa 1996; Ngobo, 1997):
- the satisfaction and the quality are subjective evaluations of the experience as service consumer, being based on comparisons between the perceived performance and a reference, complex and variable standard;

- the satisfaction is in its essence experiential and to a certain amount aims the emotional side, while the quality does not necessarily involve the personal experience, being a result of a cognitive process;

According to the temporal dimension, which allows attitude shifts, the causal links between those concepts may vary both in a positive sense, and in a negative one.

At present the client is the key actor, around whom all the activities related to the production and supply of goods and services are structured. Their satisfaction is vital if they are to use the goods/services, beyond the experiential consumption, becoming loyal clients. This is the reason for which the companies are interested in the way in which the clients perceive all the products and services on the market, appreciating them from a qualitative point of view. The quality perceived by clients is subjective, as against the expectations, the cognitive abilities, and the consumers' emotional structures and is different from the objective quality, imposed by the norms of the quality management, characterizing the supply.

Parasuraman, A. Zeithaml, V. A., Berry, L. L. (1988) put forward in their work, SERVQUAL: A multiple-item scale for measuring consumer perceptions of service quality, a scale with 25 items for the measurement of the service quality as follows:

- tangible elements: peripheral equipment, equipment and serving staff;

- reliability: the capacity of achieving the promised service under safety conditions and in a clear-cut manner;

- accommodating attitude: the kindness to answer and to provide rapid service; 
- the safety: the competence and the staff's courtesy, the capacity of inspiring trust;

- the empathy: the way in which the clients are being taken into consideration and are granted individual attention.

The Qualitative Features of the tourism products/services, which match the notion of supply, are the following (Snak O., Baron P., Neacşu N., 2001):

1) validity, which refers to the capacity of the product/service of being used;

2) reliability, that is supplying a product to the consumer under safety conditions ;

3) efficiency, appreciated through the consumer's level of satisfaction but also through the (financial) effect/effort relation;

4) integrability, that is the feature of supplying the whole range of attributes that define its content;

5) accessibility, expressed by the pricequality ratio;

6) flexibility, appreciated by the capacity of adapting to the client's requirements.

A specificity of the tourism services is the global tourism produce "all inclusive", which encompasses the organizational component, its reunion in a service package of a whole range of heterogeneous services, completely different in terms of technology and elaboration manner (transportation, hotel services, food, recreation, medical services, personal services etc.) Unless the consistency and the coherence of the whole service chain are assured, the customers' overall satisfaction will be affected, regardless of the individual qualitative level of its components. These services are characterized by a strong seasonal character of the tourism demand, upon which the managers and specialists in the field of tourism focus their numerous concerns.

The perceived quality influences the consumers' satisfaction. It results from the confrontation of the objective quality of the products and services with the consumers' expectations.

The value the consumers attach to the product devolves from the determined utility by the qualitative features of the product and its price. The price of the product matches its qualitative features and must inspire the feeling of being equitably treated to the customer.

The temporal dimension plays an important role in tourism, due to the seasonal character of the activity. The same tourism product, functionally and qualitatively speaking, may be purchased at different prices during the high-season/ low-season periods.

The marketing strategies must be oriented towards the qualitative level wished by the client and paid through the price; the evaluation of the consumer segments to which the product is addressed must be achieved from the point of view of the socioprofessional affiliation, of the age and income level.

An efficient marketing strategy has the following consequences:

- the company's profitability is tightly linked to the quality perceived by the clients and to the satisfaction degree they reach after having used the company's services;

- only a fully satisfied client may become a loyal client and will bring directly or indirectly new clients, to whom he will recommend their services;

- loyalty leads to the increase of the market share and of the sales volume, determining profit;

- a profitable company, only, has the possibility of making further investment in the development of the products and services, in adapting them to the customers' wishes and to the quality management as well.

The increase of the efficiency and of the efficacy are possible only by promoting the idea according to which the development of a 
profitable activity is achieved by means of satisfying the consumers' exigencies, while the quality perceived by the consumer must raise to their expectations.

\section{The Methodology of the Research, the Outcomes and the Discussions}

The aim of the research is to identify the way in which the consumers perceive the services of the companies under analysis and the sources that develop the customers' satisfaction.

The main objective of the paper is to highlight the Romanian company's concern in the North-East region, for the quantification and the development of the customers' satisfaction. The survey was drawn up between January 2010 and September 2010, on three companies that operate in the field of tourism, whose main activity is hotel services, restaurant, tourism agency.

The research method that was used was the achievement of a poll, on a significant sample- 180 respondents, who were randomly selected out of the company's databank. The opinions were collected both by direct talks and by e-mail. The results have been evaluated with the Likert scale but also with ordinal scales.

The sample is made of (table no. 1) 180 people, most of them being women (66.12\%), people with higher education degrees (44.5\%), active on the labour market $(81.11 \%)$, whose family is made up of 4 members (43.33\%), who subjectively appreciate their material conditions of living as being "Very good" (43.88\%).

\section{Table no. 1 Features of the Sample}

\begin{tabular}{|c|c|c|}
\hline Features of the sample & Number & $\%$ \\
\hline Total & 180 & 100 \\
\hline Sex : - feminine $(F)$ & 119 & 66.12 \\
\hline - masculine (M) & 61 & 33.88 \\
\hline Group age: $-15-24$ years & 41 & 22.77 \\
\hline$-25-54$ years & 56 & 31.11 \\
\hline$-55-64$ years & 45 & 25.00 \\
\hline -over 64 years & 38 & 10.23 \\
\hline Education level: - General and vocational & 45 & 25.00 \\
\hline - Secondary and post-secondary education & 55 & 30.50 \\
\hline- Higher-education & 80 & 44.50 \\
\hline Economic activity: $\quad$-Active & 146 & 81.11 \\
\hline -Inactive & 34 & 18.89 \\
\hline Number of people in the household: & & \\
\hline$-1-2$ Persons & 40 & 22.22 \\
\hline$-\quad 3$ Persons & 58 & 32.22 \\
\hline-4 Persons & 78 & 43.33 \\
\hline - $\quad 5$ Persons and even more & 4 & 2.22 \\
\hline Subjective self-evaluation of the material status: & & \\
\hline - Very Good & 79 & 43.80 \\
\hline - Good & 42 & 23.30 \\
\hline - Average & 39 & 21.60 \\
\hline - Satisfactory & 20 & 11.30 \\
\hline - Unsatisfactory & 0 & 0 \\
\hline People who use the Internet and e-mail on a regular basis & 134 & 74.44 \\
\hline People who use a card on a regular basis & 123 & 68.33 \\
\hline
\end{tabular}


The consumers' perceptions towards the companies' concerns of bettering the quality of the supplied services in 2009, as against the same period of the year 2008 are presented in table no. 2 .

Table no. 2 The Consumers' Perceptions on the Interest Granted to Service Quality and Customer Satisfaction in 2009 in Comparison to 2008 (\%)

\begin{tabular}{|c|c|c|c|c|c|c|c|}
\hline & \multirow[t]{3}{*}{ Total } & \multicolumn{6}{|c|}{ Interviewed people according to : } \\
\hline & & \multicolumn{2}{|c|}{ Sex } & \multicolumn{4}{|c|}{ Age groups } \\
\hline & & $\mathrm{F}$ & $\mathrm{M}$ & $\begin{array}{l}15-24 \\
\text { years }\end{array}$ & $\begin{array}{l}25-54 \\
\text { years }\end{array}$ & $\begin{array}{l}55-64 \\
\text { years }\end{array}$ & $\begin{array}{l}\text { over } 64 \\
\text { years }\end{array}$ \\
\hline $\begin{array}{l}\text { To a lower or much } \\
\text { lower degree }\end{array}$ & $11 / 6.11$ & $10 / 8.4$ & $1 / 1.6$ & 0 & $11 / 19.5$ & 0 & 0 \\
\hline The same & $80 / 44.44$ & $51 / 42.9$ & $29 / 36.3$ & $20 / 48.80$ & $21 / 37.50$ & $22 / 48.80$ & $17 / 44.7$ \\
\hline $\begin{array}{l}\text { To a higher or } \\
\text { much } \\
\text { degree }\end{array}$ & $89 / 49.44$ & $58 / 48.7$ & $31 / 62.1$ & $21 / 42.20$ & $24 / 43.00$ & $23 / 41.20$ & $21 / 44.3$ \\
\hline TOTAL & $180 / 100 \%$ & $119 / 100 \%$ & $61 / 100 \%$ & $41 / 100 \%$ & $56 / 100 \%$ & $45 / 100 \%$ & $38 / 100 \%$ \\
\hline
\end{tabular}

As it results from the data presented in table no. $2,49.44 \%$ of the sample believe that things are better or much better from the point of view of the interest granted to the services and to consumers' in 2009 in comparison with the same period of the year 2008, $44.44 \%$ believe the situation is the same, while $6.11 \%$ believe it is worse or much worse. From the point of view of structuring the opinion on sexes, $62.1 \%$ of the men perceive a higher quality level, as against $48.7 \%$ of the women. Most of the people who perceive a lower level of services in comparison with the previous year are women and fit into the age group 25-54 years. The main causes that have determined the shaping of these opinions are subjective as it results from the overall evaluation of the purchased services, (table no. 3 ) as well as of their analytic evaluation (table no. 4).

Table no. 3 ranks the main causes that have led to the change of the perceptions towards the interest granted to assuring the quality of the services and to the increase of the clients' satisfaction within the analysed companies.

Table no. 3 The Main Causes that led to the Increase of the Customers' Satisfaction, in the Case of the Companies under Analysis, in 2009 in Comparison to 2008 (\%)

\begin{tabular}{|l|l|l|l|l|l|l|l|}
\hline \multirow{2}{*}{} & \multirow{2}{*}{ Total } & \multicolumn{5}{|c|}{ Interviewed persons according to: } \\
\cline { 3 - 8 } & & \multicolumn{2}{|c|}{ Sex } & \multicolumn{5}{|c|}{ Age groups } \\
\cline { 3 - 8 } & & $\mathrm{F}$ & $\mathrm{M}$ & $\begin{array}{l}15-24 \\
\text { years }\end{array}$ & $\begin{array}{l}25-54 \\
\text { years }\end{array}$ & $\begin{array}{l}55-64 \\
\text { years }\end{array}$ & $\begin{array}{l}\text { over } 64 \\
\text { years }\end{array}$ \\
\hline $\begin{array}{l}\text { The organization manner } \\
\text { (diminishing the waiting period, } \\
\text { complying with agreements) }\end{array}$ & $68 / 40.2$ & $48 / 44.0$ & $20 / 33.3$ & $17 / 41.4$ & $18 / 40.0$ & $19 / 42.2$ & $14 / 36.8$ \\
\hline The price-quality ratio & $41 / 24.2$ & $25 / 22.9$ & $16 / 26.6$ & $10 / 24.4$ & $12 / 26.6$ & $11 / 24.4$ & $8 / 21.1$ \\
\hline Bonuses & $39 / 23.1$ & $25 / 22.9$ & $14 / 23.3$ & $9 / 22.0$ & $9 / 20.1$ & $9 / 20.1$ & $12 / 31.6$ \\
\hline The behaviour of the staff & $21 / 12.5$ & $11 / 10.2$ & $10 / 16.8$ & $5 / 12.2$ & $6 / 13.3$ & $6 / 13.3$ & $4 / 10.5$ \\
\hline TOTAL & $169 / 100 \%$ & $\begin{array}{l}109 / 100 \\
\%\end{array}$ & $\begin{array}{l}60 / 100 \\
\%\end{array}$ & $\begin{array}{l}41 / 100 \\
\%\end{array}$ & $\begin{array}{l}45 / 100 \\
\%\end{array}$ & $\begin{array}{l}45 / 100 \\
\%\end{array}$ & $\begin{array}{l}38 / 100 \\
\%\end{array}$ \\
\hline
\end{tabular}


As it results from the data presented in table no. $3,40.2 \%$ of the interviewed people have noticed improvements in the overall way of supplying services, of diminishing the waiting period, of strictly complying with the assumed engagements, while $24.2 \%$ have noticed the improvement of the price-quality ratio. Because of the global economicfinancial crisis, which has also affected the tourism services suppliers in Romania, bonus elements have been introduced with a view to keeping and rendering the customers loyal, which was a strong satisfier for $23.1 \%$ of the respondents. The analysis of the results according to age groups and sex highlights a relatively even distribution of the respondents' opinion, and therefore it does not justify further research based on this segmentation.

We notice the fact that the lowest satisfaction level is provided by the behaviour of the staff, $12.5 \%$ respectively, which represents both a huge source of satisfaction improvement and an important analysis topic for the management. The check of the reliability of the results obtained, and the further study of the satisfiers has been achieved using the second analysis scale related to the consumers' perceptions, as against the concrete aspects that characterize the supplied services.

Table no. 4 The Main Components of the Services that Have Led to the Improvement of the Consumers' Perceptions in 2009 in Comparison with 2008 (\%) Resulted from the Subjective Evaluation of the Personal Situations

\begin{tabular}{|c|c|c|c|c|c|c|c|}
\hline & \multirow{3}{*}{ Total } & \multicolumn{6}{|c|}{ Interviewed persons acc ording to : } \\
\hline & & \multicolumn{2}{|c|}{ Sex } & \multicolumn{4}{|c|}{ Age groups } \\
\hline & & $\mathrm{F}$ & $\mathrm{M}$ & $\begin{array}{l}15-24 \\
\text { years }\end{array}$ & $\begin{array}{l}25-54 \\
\text { years }\end{array}$ & $\begin{array}{l}55-64 \\
\text { years }\end{array}$ & $\begin{array}{ll}\text { over } & 64 \\
\text { years } & \end{array}$ \\
\hline $\begin{array}{l}\text { Efficiencyl } \\
\text { Possibility of being } \\
\text { integrated }\end{array}$ & $71 / 42.0$ & $49 / 45.0$ & $22 / 33.3$ & $17 / 41.4$ & $21 / 46.8$ & $19 / 42.2$ & $14 / 36.8$ \\
\hline Flexibility & $52 / 30.8$ & $35 / 27.5$ & $17 / 26.6$ & $14 / 34.2$ & $12 / 26.6$ & $15 / 33.4$ & $16 / 42.1$ \\
\hline Accessibility & $41 / 24.3$ & $25 / 22.9$ & $16 / 26.6$ & $10 / 24.4$ & $12 / 26.6$ & $11 / 24.4$ & $8 / 21.1$ \\
\hline Staff performance & $5 / 29$ & 0 & $5 / 4.60$ & 0 & $5 / 11.1$ & 0 & 0 \\
\hline TOTAL & $169 / 100 \%$ & $109 / 100 \%$ & $\begin{array}{l}60 / 100 \\
\%\end{array}$ & $\begin{array}{l}41 / 100 \\
\%\end{array}$ & $\begin{array}{l}45 / 100 \\
\%\end{array}$ & $\begin{array}{l}45 / 100 \\
\%\end{array}$ & $38 / 100 \%$ \\
\hline
\end{tabular}

The data presented in table 4 reveals the importance granted to the efficacy of service supply, for $42.0 \%$ of the respondents, but also the fact that the flexibility, the capacity to adapt and personalize the services is highly important for $30.8 \%$ of the consumers. The accessibility shaped the satisfaction for $24.3 \%$ of the consumers.

The following aspects rank in descending order when evaluating the main satisfaction factors: efficacy/integrability of supplying services, flexibility, accessibility, the employee's way of providing services being given the last rank.
Starting from the fact that the perceptions upon the service providing staff take the last rank in the hierarchy of satisfiers, we have conducted a questionnaire investigation with respect to the satisfaction of the three companies under analysis, on a significant sample of 50 respondents.

The main aspects under discussion were related to the values that predominate in their professional activity and the main causes of labour satisfaction/dissatisfaction. The evaluations have been done on the bases of the Lickert scale and of the ordinal scale. 
Table no. 5 Features of the Sample

\begin{tabular}{|c|c|c|}
\hline Features of the sample & Number & $\%$ \\
\hline Total & 50 & 100 \\
\hline $\begin{aligned} \text { Sex : } & - \text { feminine }(F) \\
& \text { - masculine (M) }\end{aligned}$ & $\begin{array}{c}39 \\
11\end{array}$ & $\begin{array}{l}78.00 \\
22.0\end{array}$ \\
\hline Age: $\begin{aligned}- & 15-24 \text { years } \\
& -25-54 \text { years } \\
& -55-64 \text { years } \\
& - \text { over } 64 \text { years }\end{aligned}$ & $\begin{array}{r}9 \\
39 \\
2 \\
0\end{array}$ & $\begin{array}{l}18.00 \\
78.00 \\
4.00 \\
0\end{array}$ \\
\hline 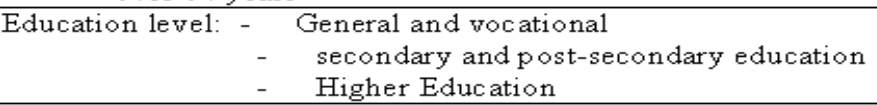 & $\begin{array}{c}8 \\
26 \\
16\end{array}$ & $\begin{array}{l}16.00 \\
52.00 \\
32.00\end{array}$ \\
\hline $\begin{array}{l}\text { The subjective self-evaluation of the remuneration level: } \\
-\quad \text { Very Good } \\
-\quad \text { Good } \\
- \text { Average } \\
-\quad \text { Satisfactory } \\
-\quad \text { Unsatisfactory }\end{array}$ & $\begin{array}{r}10 \\
12 \\
14 \\
14 \\
0\end{array}$ & $\begin{array}{c}20.00 \\
24.00 \\
28.00 \\
28.00 \\
0\end{array}$ \\
\hline $\begin{array}{lll}\text { Employees: } & - & \text { Labour contract on an undetermined } \\
\text { period } & & \\
& - & \text { Se asonal employees }\end{array}$ & $\begin{array}{r}47 \\
3\end{array}$ & $\begin{array}{c}94.00 \\
6.00\end{array}$ \\
\hline
\end{tabular}

Table no. 6 The Main Values Shared by the Employees (No/\%)

\begin{tabular}{|c|c|c|c|c|c|c|}
\hline $\begin{array}{l}\text { Values/appreciation } \\
\text { level }\end{array}$ & Total & $\begin{array}{l}\text { No/\% } \\
\text { Very } \\
\text { good }\end{array}$ & $\begin{array}{l}\text { No/\% } \\
\text { Good }\end{array}$ & $\begin{array}{l}\mathrm{No} / \% \\
\text { Neither } \\
/ \text { nor }\end{array}$ & $\begin{array}{l}\mathrm{No} / \% \\
\text { Inadequa } \\
\text { te }\end{array}$ & $\begin{array}{l}\mathrm{No} / \% \\
\text { Total } \\
\text { Inadequate }\end{array}$ \\
\hline $\begin{array}{l}\text { Cohesion with respect } \\
\text { to the company's } \\
\text { objectives (the concern } \\
\text { towards the clients, } \\
\text { complying with } \\
\text { agreements) }\end{array}$ & $\begin{array}{l}50 / 10 \\
0\end{array}$ & $10 / 20.0$ & $39 / 78.0$ & $1 / 2.0$ & 0 & 0 \\
\hline $\begin{array}{l}\text { The perceptions upon } \\
\text { the way labour is } \\
\text { organized }\end{array}$ & $\begin{array}{l}50 / 10 \\
0\end{array}$ & $41 / 82$ & $9 / 18$ & 0 & 0 & 0 \\
\hline $\begin{array}{l}\text { The perceptions upon } \\
\text { the managers' } \\
\text { behaviour }\end{array}$ & $\begin{array}{l}50 / 10 \\
0\end{array}$ & $15 / 30.0$ & $13 / 26.0$ & $8 / 16.0$ & $4 / 8.0$ & 0 \\
\hline $\begin{array}{l}\text { The perceptions upon } \\
\text { the professional ethic }\end{array}$ & $\begin{array}{l}50 / 10 \\
0\end{array}$ & $11 / 22.0$ & $19 / 38.0$ & $14 / 28.0$ & $6 / 12$ & 0 \\
\hline $\begin{array}{l}\text { The perceptions upon } \\
\text { the customers' } \\
\text { behaviour }\end{array}$ & $\begin{array}{l}50 / 10 \\
0\end{array}$ & $31 / 62.0$ & $8 / 16.0$ & $11 / 22.0$ & 0 & 0 \\
\hline
\end{tabular}

The analysis of the data presented in table 6 reveals the fact that most of the employees show cohesion with reference to achieving the objectives of the companies where they develop their activity (49/98\%) and perceive well and very well the way in which work is organized (50/100\%). As far as the managers' behaviour is concerned, although most of the employees believe it to be good and very good (38/89\%), 4 employees, respectively $8 \%$ appreciate it as being inadequate. And, in as far as the professional ethics is concerned although most of them appreciate it to be good and very good, 6 of the employees, $12 \%$ respectively, appreciate it as being inadequate.

The research has revealed that the staff's perceptions upon the clients are very good $(31 / 62 \%)$, good $(8 / 16.0)$ and average $(11 / 22.0)$.

We believe that these results do not provide an answer to the fact that, in the clients' 
opinion, the satisfaction provided by the staff's way of behaving is on the last rank.

If we are to view things from the perspective of the income level, presented in table 5 , we may draw the conclusion that the salary level is neither motivating nor satisfying, only $44 \%$ of the employees appreciate that, following the subjective self-evaluation of the income level, they are well and very-well paid for their work.

This is why we have asked each of the employees to name, the three most important causes of satisfaction and the main 3 causes of dissatisfaction at work. The synthesis of the results is illustrated in table 7.

Table no. 7 The Main Causes of Work Satisfaction/Dissatisfaction

\begin{tabular}{|l|l|l|l|}
\hline \multicolumn{1}{|c|}{$\begin{array}{c}\text { The main causes of } \\
\text { satisfaction }\end{array}$} & $\%$ & \multicolumn{1}{|c|}{$\begin{array}{c}\text { The main causes of } \\
\text { dissatisfaction }\end{array}$} & $\%$ \\
\hline Tips & 55 & The low level of the wages & 56 \\
\hline Managers' recognition & 21 & Stress & 22 \\
\hline Clients' appreciation & 20 & $\begin{array}{l}\text { The lack of promotion } \\
\text { perspectives }\end{array}$ & 11 \\
\hline Other causes & 14 & Other causes & 10 \\
\hline
\end{tabular}

The statement of the satisfaction/dissatisfaction causes at work reveal the fact that the employees are not sufficiently taken into account within the policies promoted by the companies under analysis and explain the fact that the employees grant average attention to the clients, depending on the manner in which they are treated, and which the consumers rank on the last rank among satisfiers.

\section{Conclusions}

The policies of the companies that operate in the field of tourism, in Romania, have developed as far as the vision regarding the quality of the tourism services, the assurance and the development of the customers' satisfaction.

The future research, continuing this one, will try to overpass the limitations of present approach, developing the role and importance of the Romanian tourism industry in developing the whole economy and raise the standard of living, affected by the economic-financial crisis.

Therefore, the efforts of technological equipment and environment development, of raising the comfort level must be accompanied by policies related to raising the employee's training and motivation level so that they might have the capacity to answer in the most anticipatory manner to their clients' needs and wishes. We notice that the companies under analysis apply the principles of the technicist development, mainly, emphasising the logistics, the organisational side, discrepancies being visible between these aspects and the development of the Human Resources.

The interviewed consumers have noticed improvements in the overall way of providing services, of diminishing the waiting period, of strictly complying with the engagements, bettering the price-quality ratio. What is needed, besides the importance granted to efficiency when providing services, is the increase of flexibility, of the capacity to adjust and personalize the services offered to the consumers. The Human Resources Management also needs some changes able to motivate the personnel and increase their competences. Within the companies under analysis, the employees have been identified as the most important source, which may increase the customers' satisfaction. 
Under the current circumstances, without a policy directed towards the quality management, which emphasizes the development of the customers' satisfaction, there is no possibility to create the conditions for the development of some profitable activities.

The limits of this survey consist in the fact that it may not be generalized, the results of the research and the recommendations being applicable strictly to the companies under analysis.

\section{References:}

Balfet, M. (1997). L'Audit Marketing Touristique, Economica, Paris, 1997.

Day, R. L. (1984). 'Modeling Choices among Alternative Responses to Satisfaction Involvement,' Advances in Consumer Research, 11.

Evrard, Y. (1993). "La Satisfaction des Consommateurs: Etat des Recherches," Revue Francaise du Marketing, 155/145, pp53.65

Holt, D. B. (1995).'How Consumer Consume: A typology of Consumption Practices, ' Journal of Consumer Research , 22.

Howard, J. A. \& Sheth, J. N. (1969). The Theory of Buyer Behavior, John Wiley \& Sons, New York.

Hunt, S. D. \& Morgan, R. M. (1994). 'Theory of Relationship Marketing,' Journal of Marketing , 53.

Lache, C. (2005). 'Măsurarea Satisfacției Clienților, în Volumul Economia Românească în Contextul Integrării Europene,' Anuar Tomul XV, Universitatea "Petre Andrei”, Iaşi, pp 349.359.

Lache, C. (2010). Comportamentul Consumatorilor, Performantica, Iaşi, pp 208.229.

Lache, C. (2010). 'Communication L'accroissement de la Satisfaction des Consommateurs, Élément Central des Politiques de Marketing in the Second
International ETC Conference: Law,' Economic policies, Communitarian development, Bacau, Romania, May, 5th.7th 2010.

Lache, C. S. A. (2010). 'The Analysis of Consumers' Behavior in the Frame of World Economic Crisis,' Revista Metalurgia International nr.11., Bucuresti, p 107.

Maddox, R. N. (1981). "Two-Factor Theory Consumer Satisfaction: Replication and Extension," The Journal of Consumer Research , 8

Ngobo, P. V. (1997) "Qualité perçue et Satisfaction des Consommateurs: un état des Recherche," Revue française du Marketing, nr. 163 , pp 460.469.

Oliver, R. L. (1980). "A Cognitive Model the Antecedents and Consequences of Satisfaction Decision," Journal of Marketing Research, November, 17, pp 460.469.

Oliver, R. L. (1993). 'Assessing the Dimensionality of the Consumer Research,' June, 20, pp 23.45

Oliver, R. L. \& Swan, J. E. (1989). "Consumer Perceptions of Interpersonal Equity and Satisfaction in Transaction," The Journal of Marketing , 53.

Parasuraman, A., Zeithaml, V. A. \& Berry, L. L. (1988). "SERVQUAL: A Multiple.Item Scale for Measuring Consumer Perceptions of Service Quality," Journal of Retailing , 64.

Ray, D. (2002). Mésurer et Développer la Satisfaction Clients, Ed. D'Organisation, Paris, p10.

Snak, O., Baron, P. \& Neacşu, N. (2001). "Economia Turismului," Editura Expert, Bucuresti, 422.429.

Wetsbrook, R. A. \& Reilly, M. D. (1983). "Value Percept Disparity: An Alternative to the Disconfirmation of Expectations Theory of Customer Satisfaction," Advances in Consumer Research, Associations for Consumer Research, pp 256.261. 